\title{
Sero-prevalence and risk factors of human brucellosis among febrile patients visited health institutes at Awra and Gulina district, Afar Region, Ethiopia
}

Biruk Zerfu ( $\sim$ Biruk.zerfu@aau.edu.et )

Addis Ababa University https://orcid.org/0000-0002-2406-5971

Sintayehu Mehari

Addis Ababa University

Kassu Desta

Addis ababa University

Research article

Keywords: brucellosis, sero-prevalence, febrile, risk factors, Ethiopia

Posted Date: October 28th, 2020

DOI: https://doi.org/10.21203/rs.3.rs-96814/v1

License: (c) (1) This work is licensed under a Creative Commons Attribution 4.0 International License.

Read Full License 


\section{Abstract}

Background: Brucellosis is an important neglected bacterial zoonotic disease that affects animals and humans for decades. The aim of this study was to determine the sero-prevalence and risk factors of human brucellosis among febrile patients visited health institutes at Awra and Gulina district of Afar region Ethiopia.

Methods: A purposive cross-sectional study was conducted among 444 febrile patients visiting two health institutes in Awra and Gulina district of Afar region from February to May 2019. A 3-5ml blood samples were collected, thick and thin blood films were examined microscopically for malaria; serum was separated and tested antibody of Brucella using Rose Bengal Plate Test (RBPT) and positives ones were further subjected to ELISA. Data were entered using EpiData3.1 and analyses were performed using StataSE 14.

Results: A total of 444 febrile individuals ( $59.5 \%$ female) of age ranging from 2-83 years (mean= 26.1, SD $= \pm 11.8$ ) participated in this study. The overall sero-prevalence of brucellosis was $31.5 \%$ and $15.8 \%$ by RBPT and ELISA, respectively and $4.3 \%$ of the patients were positive for $P$. falciparum. Being male $(A O R=2.41,95 \% \mathrm{Cl}: 1.36-4.26, \mathrm{p}<0.002)$, drinking raw milk (AOR=15.42, 95\% Cl: $5.17-45.95, \mathrm{p}<0.001)$ and touching aborted fetus/discharges without protectives (AOR=3.70,95\% Cl: $1.61-8.50, p=0.02$ ) were independently associated with brucellosis among febrile patients.

Conclusion: Human brucellosis is highly prevalent in pastoralist patients presenting with fever in this study area. Consumption of raw milk and contamination with aborted or discharge of animals are major risk factors. Hence, brucellosis should be considered as an important public health problem in this study area.

\section{Background}

Brucellosis is a neglected bacterial zoonotic disease that has been affecting animals and humans for years [1]. The annual global human brucellosis case reports are about half a million [2]. The poor surveillance systems in developing countries like Ethiopia have led to underestimation of the true burden of the cases of brucellosis [3]. Several developed countries eradicated brucellosis as but it remains endemic in areas like northern and eastern Africa, India, central Asia, Mexico and central and southern America [4]. In Sub-Saharan Africa, animal brucellosis ranges from 10.2 to $25.7 \%$ [5]. Human beings can acquire the infection and can have a potential threat of re-emergence in several countries with an increasing incidence of infection in cattle [5].

Brucellosis is an occupational hazard for veterinarians, laboratory workers, slaughterhouse workers and farmers which can be acquired through either contact with infected animals, their tissues or animal products. The bacteria enter human through wounds or abrasion of skins/mucous membranes during contact with infected animals, and during consumption of raw or unpasteurized milk and dairy products of such milk [6]. Brucellosis in human is manifested mainly by intermittent or irregular fever, headache, 
weakness, profuse sweating, chills, arthralgia, depression, weight loss, hepatomegaly and splenomegaly[7] and rarely arthritis, spondylitis, osteomyelitis, epididymitis and orchitis, but in severe cases neuro brucellosis, liver abscesses and endocarditis have been reported [8].

Since human brucellosis has wide clinical feature presentations, it mimics many communicable and noncommunicable diseases like malaria, typhoid fever, typhus, rheumatic fever, joint diseases and others. These features pose a diagnostic difficulty for brucellosis especially in developing countries like Ethiopia because, they adhere mostly on apparent clinical signs and symptoms as diagnostic indicators to rule out diseases. In Ethiopia, determination of risk factors and health intervention of human brucellosis is not yet undertaken routinely due to lack of effective and appropriate diagnostic facilities $[9,10]$.

On the other hand, $75 \%$ of the Ethiopia's landmark is favorable for malaria transmission that has left about $68 \%$ of the total population at risk of malaria [11]. However, Ethiopia scaled up malaria intervention programs towards elimination that has achieved $40 \%$ reduction of malaria cases and increased capacity of case confirmation of presumed malaria diagnosis from $54 \%$ in 2013 to $87 \%$ in 2017 [12]. But the intervention has left abandoned those diseases with clinical features similar to malaria like brucellosis as undiagnosed and untreated. The current study area is a pastoral and agro-pastoral that rears camel, sheep, goat and cattle. Some studies have showed that animal brucellosis is highly distributed and the livelihood of the population is very close to animals that create potential risk factors to acquire brucellosis [13-15]. Nevertheless, human brucellosis has been rarely surveyed either as misdiagnosed or abandoned at all due to similarity of signs and symptoms presumably with malaria or unfamiliarity of health care workers with the disease and its epidemiology in this area $[16,17]$. The aim of this study was to determine the sero-prevalence and risk factors of human brucellosis among febrile patients visiting health institutes in Awra and Gulina District of Afar region, Ethiopia

\section{Methods}

Study setting and population

The study was conducted in Kelwani primary hospital and Derayitu health center of Awra and Gulina district of Afar Region which is found in the north eastern part of Ethiopia. The majority of the communities are pastoralists whose livelihoods depend on livestock, specifically camels, cattle and small ruminants while few are practicing agro-pastoralist and growing crops by irrigation of Awash river.

Study design and sample size determination

A health institution based cross-sectional study design was used to determine sero-prevalence and risk factors of brucellosis among febrile patients visiting health institutes of Awra and Gulina district of Afar region, Ethiopia from February to May 2019. The finding of previous community based sero-prevalence of brucellosis (4.4\%) in other pastoral area of the community of the region was used to estimate the sample size [17]. Based on this information, the calculated sample size, at $95 \%$ confidence level, $5 \%$ degree of accuracy and with $10 \%$ compensation for refusal, was 444 respondents. 
Study participants, sample and data collection

All patients older than two years who had fever and measured axial body temperature $\geq 37.5^{\circ} \mathrm{C}$ during data collection period, willing to provide written consent/assent for participation, was recruited to the study. A total 444 respondents were interviewed in their local language (Afar language) using a structured questionnaire to collect socio-demographic characteristics, sex, age, educational status, marital status, occupational status, residential address (urban/rural), potential risk factors: milk source (large ruminants, small ruminates or camels), ways of milk consumption either raw or boiled, experience of milk consumption from aborted animals, exposure to aborted fetus/ materials of animal without protective equipment, and the clinical features they felt along the onset of days of the features. A 3-5 ml of venous blood was collected from each febrile patients using plain vacutainer tube. Thin and thick blood smears were prepared immediately from each blood samples for the diagnosis of malaria. The remaining sample was kept at room temperature for 30 minutes to facilitate clotting and centrifuged at $3000 \mathrm{rpm}$ for 5 minutes to get clear serum. All sera were separated in a labeled $1.8 \mathrm{ml}$ Cryotubes, transported to Addis Ababa Federal police laboratory in a cold box and stored at $4{ }^{\circ} \mathrm{C}$ until testing.

Blood examination for malaria

Malaria was detected from Giemsa stained blood films following the guideline of Ethiopian Ministry of Health for the diagnosis of malaria and identification of Plasmodium species at the health institute [18].

Blood examination for brucellosis:

Two types of serological tests were used to determine sero-prevalence of brucellosis.

The sera were screened using Rose Bengal Plate Test (RBPT) and positive reactors were further subjected to ELISA. All sera and RBPT reagent and controls were taken out from refrigerator and kept at room temperature for 30 minutes to screen for anti-Brucella antibodies in Addis Ababa Federal police laboratory. As previously described [19], the smooth, attenuated stained Brucella antigen suspension was mixed with positive and negative controls and serum on circular test card. If specific antibody to Brucella antigen is present in the serum, it reacts with the antigen suspension to produce visible agglutination after shaking on a low speed shaker for four minutes. No agglutination indicates absence of specific antibodies to Brucella antigens. All sera positive for Brucella antibody using RBPT were transported to Armeaur Hansen Research Institute (AHRI) to confirm the anti-Brucella antibodies by IgG ELISA. According to manufacturer's guideline (Demeditec Brucella abortus IgG ELISA DEBRU01, Germany), qualitative anti-Brucella IgG ELISA was determined based on the principle of the spectrophotometric enzyme immunoassay at the wave length of $450 \mathrm{~nm}$. The calculated absorption for the patient sera were compared with the value of the cut-off standard. If the value of the sample was higher than the cut-off standard, it was considered as positive whereas below the cut-off standard, the result was considered negative.

\section{Data analysis}


Descriptive analysis was used to summarize the data in the forms of frequencies and percentages. Pearson Chi2 test was used for testing relationships between brucellosis and malaria infection with each demographic characteristic of study participants. Univariate logistic regression analyses were conducted to establish the association of the putative risk factors with brucellosis and odds ratio at $95 \%$ confidence intervals $(\mathrm{Cl})$ was considered. All risk factors significant at univariate analysis were considered for multivariate logistic regression analysis to determine the independent association between risk factors and brucellosis at $95 \% \mathrm{Cl}$. P-value below 0.05 was considered statistical significance.

\section{Ethical Consideration}

This study received ethical clearance from the Ethical Review Board of Department of Medical Laboratory Science, College of Health Sciences, Addis Ababa University (DRERC/410/19/MLS). Permission was obtained from Derayitu Health center and Kelwani Primary Hospital. Participants' information sheet, which contains the objective of the study, inclusion/exclusion criteria, the required data and methods of data collection as well as informed consent/assent document, were prepared in Amharic the national language of the country. Then, the elements of participants' information sheet initially were orally translated to the local language (Afar Language) and described to each of the study participants or parents in case of children under 18 years by trained local health personnel. Informed consent was obtained from the participants and/or assent in children aged between 12 and 18 years. Blood sample was collected under aseptic condition by experienced laboratory technicians. Study participants who were found positive for malaria were treated according to malaria treatment guideline and the rest were treated with different antibiotics accordingly as per clinician presumptive diagnosis.

\section{Results}

\section{Socio-demographic characteristics}

A total of 444 febrile individuals (female, 59.5\%), with age range of 2 to 83 (mean $=26.1, S D= \pm 11.8$ ) years participated in the study, with the majority, 241 (54.3\%) of the participants between 15-29 years old. Among 444 febrile study participants, 249 (56.1\%) were agro- and/or pastoralists 201 (45.3\%) were illiterate, $313(70.5 \%)$ married, and $347(78.1 \%)$ were rural residents. The clinical features were fever 444 (100\%), headache 340 (76.6\%), vomiting 139 (31.1\%), general malaise $128(28.6 \%)$, joint pain 125(28.2\%) and general weakness $118(26.6 \%)$ and the duration of the reported illness ranged from 1 to 30 days, with most of the patients $289(65.1 \%)$ felt the illness for the duration of 1-3 days (Table 1).

\section{Laboratory results}

Of all (444) tested sera for brucellosis, the sero-prevalence of brucellosis was found 31.5\% (140) by RBPT. From the entire sero-positive (140), 50 \% (70) were found positive by ELISA. The combined seroprevalence was $15.8 \%$ (70/444). Brucellosis was frequently detected in males than females $37.8 \%$ vs. $\left.27.3 \%, X^{2}=5.47, p=0.019\right)$, among illiterate than compared to those with primary school and above 
$\left(20.4 \%\right.$ vs. $\left.11.9 \%, X^{2}=6.21 ; p=0.045\right)$ and among rural residents than among urban residents $(33.7 \%$ vs. $23.7 \%, X^{2}=3.52, p=0.041$ ) (Table 2).

Among all patients (444) tested for malaria, 4.3\% (19) were found positive for $P$. falciparum by microscopic detection of Giemsa stained thick and thin blood films and therefore, were classified as malaria infected. Malaria cases were more common among males than females $(7.2 \%$ vs. $2.3 \%, \mathrm{X} 2=6.14$, $\mathrm{p}=0.01)$ and non-married than married $(7.6 \%$ vs. $2.9 \%, \mathrm{X} 2=5.10, \mathrm{p}=0.02)$. The frequency of $P$. falciparum malaria was high in the age group between $2-14$ years $(10.3 \%, X 2=7.66, p=0.05)$ (Table 3$)$.

\section{Potential risk factors for brucellosis}

At univariate logistic regression analysis, drinking raw milk (COR=27.71, 95\% Cl: $3.59-213.68, p=0.001)$, drinking milk from aborted animal ( $\mathrm{COR}=2.87,95 \% \mathrm{Cl}: 1.49-5.54, \mathrm{p}=0.002)$ and touching aborted fetus/discharges without protective equipment ( $\mathrm{COR}=2.82,95 \% \mathrm{Cl}: 1.16-6.86, p=0.022)$, were significantly associated with the occurrence of human brucellosis among these febrile patients (Table 4).

Multivariate logistic regression analysis model was built in to measure the relationship between seropositivity for brucellosis and independent variables. All socio-demographic factors and potential risk factors that showed $p$-values $<0.05$ in the univariate analysis were considered in the final multivariable logistic regression model. Being male (AOR=2.41,95\%Cl: $1.36-4.26, \mathrm{p}<0.002)$, drinking raw milk (AOR=15.42, 95\% Cl: $5.17-45.95, p<0.001)$ and touching aborted fetus/discharges without protective $(\mathrm{AOR}=3.70,95 \% \mathrm{Cl}: 1.61-8.50, \mathrm{p}=0.02)$ were associated with higher odds of having brucellosis infection among febrile patients (Table 5).

\section{Discussion}

This institution-based cross-sectional study identified 31.5\% (140/444) positive by screening test (RBPT) for brucellosis, of which $50 \%$ ( $70 / 140$ ) of them were confirmed positive by ELISA. Hence, the overall combined sero-prevalence of brucellosis was found $15.8 \%$ (70/444) and the prevalence of malaria was $4.3 \%$ (19/444) among febrile study patients. This study showed that there is high prevalence of brucellosis than malaria among febrile individuals of this pastoral area which demanding a public health consideration of neglected zoonotic brucellosis.

The prevalence of $P$. falciparum, was $4.3 \%$ and $P$. vivax was not detected. The result is lower than the previous health institution based studies carried out before full implementation of the intervention programs in Ethiopia such as in 2013 (51.5\%) [20], in 2015(17\%) [21], in 2016 (43.8\%)[22]. This significant reduction of malaria prevalence may be the impact of scaling up of malaria intervention programs towards elimination introduced since 2016 in the country [23]. Malaria infection was found common among male and young children which is most likely due to the fact that as observed males traditionally move from home for a short or long time camping along livestock for grazing and naïve immunity of young children for malaria parasites. Even if the prevalence of malaria was found relatively 
low due to the prevention and control measures employed by the country towards to eliminate from the country [23], sustainable devotion of control and prevention need to be enhanced by addressing all infection. Because there would be a possibility of resurge of malaria epidemic and this identified $P$. falciparum which is the most severe of malaria may impact the health of the community in this study area.

The prevalence of human brucellosis is felt within the livestock prevalence range (10.2-25.7\%) of lowerand middle-income countries [5].This finding showed that the source of human brucellosis is most likely animals which are infected and served as reservoirs in this study area. The result is in agreement with the findings from febrile individuals of different Sub-Saharan African countries like Tanzania (15.4\%), Northern Uganda (18.7\%), and Northeastern Kenya (13.7\%) [24-26]. This result revealed that human brucellosis is a febrile illness and highly circulating among sub-Saharan African countries including Ethiopia. The result was higher than the 2016 Ethiopian domestic animal brucellosis estimate, 5.3\%in goats, $2.9 \%$ in cattle and camel and $2.7 \%$ in sheep but it was concurrent with the human estimates of pastoral area (17.4\%) and higher than the human estimates of sedentary area (3.1\%) [32].The confirmatory finding of this study was lower than health facility based studies in Borena (34.9\%) South Ethiopia and Metema (29.4\%)North Ethiopia [27], but it is quite higher than many previous findings of health facility based studies of febrile individuals in other part of the country, southwestern Ethiopia, 1$3.6 \%[21,28]$ and $2.15 \%$ in central Ethiopia[29]. The possible explanation for the difference in the seroprevalence could be due to difference in the sampling design schemes used, the number of samples, exposure to Brucella species and type of diagnostic tests used.

The study identified residential area and sex as important risk factors for human brucellosis. Rural residents and being male who lived in this area were about three and half and five and half times more likely to be sero-positive for brucellosis compared to urban residents and females, respectively. This finding is in agreement with other studies in Uganda and Egypt [24,30], which might be due to male individuals having frequent contact with animal than females.

This study also identified consumption of raw milk and contacts with aborted fetus/discharges without protective equipment to be associated with brucellosis, which is in line with other couple of study findings in Uganda [24,31]. This finding is supported by WHO report which revealed contact with infected materials such as aborted fetus, placenta, urine, manure and carcass has been reported to cause human brucellosis in $60-70 \%$ of cases [2]. The traditional habits of consumption of unpasteurized milk and fresh cheese and contamination of animal discharge are particularly common among remote areas like this study area which requires attention to create awareness on possible risk of acquiring brucella and other zoonotic infections.

This study has a few limitations. First, since it was a purposive cross-sectional study, we recruited only febrile individuals that visited health facilities that left behind apparently healthy chronic patients and during self-reporting there would be recall bias by the participants for possible factors associated to the occurrence of brucellosis in humans that weaken the inference of the finding. The other limitation is the 
test being based on serological tests; the reported sero-prevalence of brucellosis could be difficult to differentiate from previous infection.

\section{Conclusion}

Human brucellosis is high among pastoral patients presenting with febrile illness in Ethiopia.

Consumption of raw milk and exposure to animal discharge could lead to significant risk of infection with Brucella. Brucellosis presents clinical features indistinguishable from other febrile illness like malaria, and highly accurate diagnostic tools like ELISA are crucial for proper febrile disease management. The community based investigations that could address asymptomatic brucellosis, studies designed to identify the circulating Brucella species and drug profile, and study that can study similarity and difference of the species among humans and animals need to be introduced in this study area.

\section{Abbreviations}

AHRI

Armeaur Hansen Research Institute

AOR

Adjusted Odds Ratio

COR

Crude Odds Ratio

ELISA

Enzyme Linked Immunosorbent Assay

RBPT

Rose Bengal Plate Test

WHO

World Health Organization

\section{Declarations}

\section{Acknowledgments}

The authors would like to thank study participants, Kelwani primary hospital and Derayitu health center staff members, Federal Regional Laboratory, and Armeaur Hansen Research Institute for their valuable support during field sample collection.

\section{Author's Contributions}

BZ participated in the study conception, design, data collection, laboratory work, data analysis, data interpretation and manuscript writing. SM participated in its laboratory work, collection, data analysis, data interpretation and manuscript writing. KD participated in its design, data analysis, data interpretation and manuscript writing. 


\section{Funding}

The study was not financially supported but ELISA kit was supported by Armeaur Hansen Research Institute

\section{Availability of data and materials}

The datasets used and/or analysed during the current study available from the corresponding author on reasonable request.

\section{Ethics declarations}

\section{Ethical approval and consent to participate}

The study obtained ethical clearance from Ethical and Review Committee of Department of Medical Laboratory Science, College of Health Science, Addis Ababa University (DRERC/410/19/MLS).

Permission to conduct the study was also obtained from Derayitu Health center and Kelwani primary Hospital. Written informed consent was obtained from each of the study participants and from their parent or guardian for those who were less than 18 years.

\section{Consent for publication}

Not applicable

\section{Competing interests}

The authors declare that they have no competing interests.

\section{Competing interests}

The authors have no conflict of interests concerning the work reported in this paper

\section{References}

1. Tumwine G, Matovu E, Kabasa JD, Owiny DO, Majalija S. Human brucellosis: sero-prevalence and associated risk factors in agro-pastoral communities of Kiboga District, Central Uganda. BMC Public Health. 2015;15(1):900. doi:10.1186/s12889-015-2242-z.

2. Corbel MJ, Alton JJ, Banal M, Diaz R, Dranovskaia BA, Elberg SS, et al. Brucellosis in humans and animals. WHO Press. 2006. ISBN:9241547138.

3. Dean AS, Crump L, Greter H, Schelling E, Zinsstag J. Global Burden of Human Brucellosis: A Systematic Review of Disease Frequency. PLoSNegl Trop Dis 2012; 6(10): doi:10.1371/journal.pntd.0001865.

4. Majalija S, Luyombo P, Tumwine G. Sero prevalence and associated risk factors of Brucellosis among Malaria negative febrile out patients in Wakiso district, Central Uganda. BMC Res Notes. 
2018;11(1):803. doi:10.1186/s13104-018-3907-3.

5. Gemechu R. Brucellosis and Its Control through One-Health Approaches in Ethiopia. J Vet Med Res. 2017;4(3):1080. ISSN:2378-931X.

6. Njeru J, Wareth G, Melzer F, Henning K, Pletz M, Heller R, et al. Systematic review of brucellosis in Kenya: disease frequency in humans and animals and risk factors for human infection. BMC Public Health. 2016;16(1):853. doi:10.1186/s12889-016-3532-9.

7. Bouley AJ, Biggs HM, Stoddard RA, Morrissey AB, Bartlett JA, Afwamba IA, et al. Brucellosis among Hospitalized Febrile Patients in Northern Tanzania. The Am J Trop Med Hyg. 2012;87(6):1105-11. doi:10.4269/ajtmh.2012.12-0327.

8. Ogbodo S, Isiofia O, Uzodinma B. Co-existence and seroprevalence of brucellosis in a malariaendemic metropolis of southeastern Nigeria. J Exp Res.2016; 4(2). doi:10.4102/ojvr.v83i1.1002.

9. Migisha R, Nyehangane D, Boum Y, Page AL, Zúñiga-Ripa A, Conde-Álvarez R, et al. Prevalence and risk factors of brucellosis among febrile patients attending a community hospital in south western Uganda. SciRepo. 2018;8:15465. doi:10.1038/s41598-018-33915-9.

10. Kunda J, Fitzpatrick J, Kazwala R, French NP, Shirima G, MacMillan A, et al. Health-seeking behavior of human brucellosis cases in rural Tanzania. BMC Public Health. 2007;7(1):315. doi:10.1186/14712458-7-315.

11. Adhanom T, Witten HK, Getachew A, Seboxa T. Malaria. In: Berhane Y, Hailemariam D, Kloos H, editors. The epidemiology and ecology of health and disease in Ethiopia. Ababa Addis: Shama. PLC; 2006. pp. 556-76.

12. PMI. President's Malaria Initiative: Ethiopia - Malaria Operational Plan FY 2019. Source: CDC, US DOS, USAID; 2018.

13. Gumi B, Firdessa R, Yamuah L, Sori T, Tolosa T, Aseffa A, et al. Seroprevalence of Brucellosis and QFever in Southeast Ethiopian Pastoral Livestock. J Vet Sci Med Diagn. 2013;2:1. doi:10.4172/23259590.1000109 .

14. Tschopp R, Bekele S, Moti T, Young D, Aseffa A. Brucellosis and bovine tuberculosis prevalence in livestock from pastoralist communities adjacent to Awash National Park, Ethiopia. Prev Vet Med. 2015;120:187 - 94. doi:10.1016/j.prevetmed.2015.03.004.

15. Yohannes M, Degefu H, Tolosa T, Belihu K, Cutler R, Cutler S. Brucellosis in Ethiopia. Afr J Microbiol Res. 2013;7:1150-57. doi:10.5897/AJMR12.738.

16. Pappas G, Papadimitriou P, Akritidis N, Christou L, Tsianos EV. The new global map of human brucellosis. Lancet Infe Dis. 2006;6(2):91-9. doi:10.1016/S1473-3099(06)70382-6.

17. Zerfu B, Medhin G, Mamo G, Getahun G, Tschopp R, Legesse M. Community-based prevalence of typhoid fever, typhus, brucellosis and malaria among symptomatic individuals in Afar Region, Ethiopia. PLoSNegl Trop Dis. 2018; 12(10). doi:10.1371/journal.pntd.0006749.

18. Federal Ministry of Health. National Malaria Guidelines, 3rd Edn. Addis Ababa, Ethiopia. 2012. . 
19. Diaz R, Casanova A, Ariza J, Moriyon I. The Rose Bengal Test in human brucellosis: a neglected test for the diagnosis of a neglected disease. PLoSNegl Trop Dis 2011; 5(4). doi:10.1371/journal.pntd.0000950.

20. Tadesse $\mathrm{H}$, Tadesse $\mathrm{K}$. The etiology of febrile illnesses among febrile patients attending Felegeselam Health Center, Northwest Ethiopia. Amer J Biomed Life Sci. 2013;1:58-63. doi:10.11648/j.ajbls.20130103.14.

21. Feleke SM, Animut A, Belay M. Prevalence of Malaria among Acute Febrile Patients Clinically Suspected of Having Malaria in the Zeway Health Center, Ethiopia. Jpn J Infect Dis. 2015;68:55-9. doi:10.7883/yoken.JJID.2013.062.

22. Hailu T, Alemu M, Mulu W, Abera B. Incidence of Plasmodium infections and determinant factors among febrile children in a district of Northwest Ethiopia; a cross- sectional study. Trop Dis Travel Med Vacci. 2018;4:8. doi:10.1186/s40794-018-0069-1.

23. Deribew A, Dejene T, Kebede B, Assefa GT, Melaku YA, Misganaw A. Incidence, prevalence and mortality rates of malaria in Ethiopia from 1990 to 2015: analysis of the global burden of diseases. Malar J. 2017;16:271. doi:10.1186/s12936-017-1919-4.

24. Muloki HN, Erume J, Owiny DO, Kungu JM, Nakavuma J, Ogeng D, et al. Prevalence and risk factors for brucellosis in prolonged fever patients in post-conflict Northern Uganda. Afr Health Sci. 2018;18(1):22-8. doi:10.4314/ahs.v18i1.4.

25. Mukhtar F. Brucellosis in a high-risk occupational group: sero-prevalence and analysis of risk factors. J Pak Med Asso. 2010; 60(12):1031-4. ISBN: 0030-9982.

26. Chipwaza B, Mhamphi GG, Ngatunga SD, Selemani M, Amuri M, Mugasa JP, Gwakisa PS. Prevalence of bacterial febrile illnesses in children in Kilosa district, Tanzania. PLoSNegl Trop Dis. 2015; 9(5). doi:10.1371/journal.pntd.0003750.

27. Regassa G, Mekonnen D, Yamuah L, Tilahun H, Guta T, Gebreyohanis A, et al. Human Brucellosis in Traditional Pastoral Communities in Ethiopia. Int J Trop Med. 2009;4(2):59-64. 1816-3319.

28. Tolosa T, Regassa F, Belihu K, Tizazu G. Brucellosis among patients with fever of unknown origin in Jimma University Hospital, Southwestern Ethiopia. Eth J Heal Sci. 2007; 17(1):59-63. ISBN:10291857.

29. Tibeso G, Ibrahim N, Tolosa T. Sero-Prevalence of Bovine and Human Brucellosis in Adami Tulu, Central Ethiopia. World Appl Sci J. 2014;31:776-80. doi:10.5829/idosi.wasj.2014.31.05.1543.

30. Lobna MA, Khoudair MR, Osman SA. Sero Diagnosis of Brucellosis by Using Simple and Rapid Field Tests with Emphasis on Some Possible Risk Factors in Humans. Global Vet. 2014;12(3):320-5. doi:10.5829/idosi.gv.2014.12.03.82146.

31. Migisha R, Nyehangane D, Boum Y, et al. Prevalence and risk factors of brucellosis among febrile patients attending a community hospital in south western Uganda. Sci Rep. 2018;8:915-9. doi:10.1038/s41598-018-33915-9.

32. Tadesse G. Brucellosis Seropositivity in Animals and Humans in Ethiopia: A Metaanalysis.2016; PLoSNegl Trop Dis 10(10). doi: 10.1371/journal.pntd.0005006. 


\section{Tables}

Table 1: The socio- demographic characteristics of the study participants $($ № $=444)$

\begin{tabular}{|c|c|c|}
\hline Factors & & № (\%) \\
\hline \multirow[t]{2}{*}{ Sex } & Male & $180(40.5)$ \\
\hline & Female & $264(59.5)$ \\
\hline \multirow[t]{4}{*}{ Age } & $2-14$ & $58(13.1)$ \\
\hline & $15-29$ & $241(54.3)$ \\
\hline & $30-44$ & $111(25.0)$ \\
\hline & $\geq 45$ & $34(7.6)$ \\
\hline \multirow[t]{2}{*}{ Educational status } & Illiterate & $201(45.3)$ \\
\hline & Primary school and above & $243(54.7)$ \\
\hline \multirow[t]{2}{*}{ Marital status } & Married & $313(70.5)$ \\
\hline & Non married & $131(29.5)$ \\
\hline \multirow[t]{2}{*}{ Residents } & Urban & $97(21.9)$ \\
\hline & Rural & $347(78.1)$ \\
\hline \multirow[t]{2}{*}{ Occupation } & Agro-/Pastoralist & $249(56.1))$ \\
\hline & Others* & 195(43.9) \\
\hline \multirow[t]{6}{*}{ Clinical features } & Fever & $444(100.0)$ \\
\hline & Headache & $340(76.6)$ \\
\hline & General weakness & $118(26.6)$ \\
\hline & Vomiting & $139(31.1)$ \\
\hline & Malaise & $127(28.6)$ \\
\hline & Joint pain & $125(28.2)$ \\
\hline \multirow[t]{2}{*}{ Onset days of febrile } & 1-3 days & $289(65.1)$ \\
\hline & More than 3 days & $155(34.9)$ \\
\hline
\end{tabular}

*Daily laborer, Governmental workers and students

Table 2: Demographic characteristics and distribution of brucellosis among study respondents $(№=444)$ 


\begin{tabular}{|c|c|c|c|c|c|c|}
\hline Factors & & $\begin{array}{l}\text { Noo } \\
\text { tested }\end{array}$ & $\begin{array}{l}\text { No } \\
\text { RBPT've } \\
\text { (\%) }\end{array}$ & $\begin{array}{l}\text { № } \\
\text { ELISA } \\
(\%) \\
\text { (\%) }\end{array}$ & $\begin{array}{l}\text { Sero+ve at over } \\
\text { all (\%) }\end{array}$ & $\begin{array}{l}\mathrm{X}^{2} ;{ }^{P} \\
\text { value }\end{array}$ \\
\hline \multirow[t]{2}{*}{ Sex } & Male & 180 & $68(37.8)$ & $42(61.8)$ & $42(23.3)$ & \multirow{2}{*}{$\begin{array}{l}\text { 13.05; } \\
<0.001\end{array}$} \\
\hline & Female & 264 & $72(27.3)$ & $28(38.9)$ & $28(10.6)$ & \\
\hline \multirow[t]{4}{*}{ Age } & $2-14$ & 58 & 18(31.0) & $7(38.9)$ & $7(12.1)$ & \multirow{4}{*}{$\begin{array}{l}3.58 \\
0.311\end{array}$} \\
\hline & $15-29$ & 241 & $77(32.0)$ & $37(48.1)$ & $37(15.4)$ & \\
\hline & $30-44$ & 111 & $34(30.6)$ & $17(50.0)$ & 17(15.3) & \\
\hline & $\geq 45$ & 34 & $11(32.4)$ & $9(81.8)$ & $9(26.5)$ & \\
\hline \multirow{2}{*}{$\begin{array}{l}\text { Educational } \\
\text { status }\end{array}$} & Illiterate & 201 & $71(35.3)$ & $41(57.8)$ & $41(20.4)$ & \multirow{2}{*}{$\begin{array}{l}6.21 \\
0.045\end{array}$} \\
\hline & $\begin{array}{l}\text { Primary school } \\
\text { and above }\end{array}$ & 243 & $69(28.4)$ & $29(40.0)$ & $29(11.9)$ & \\
\hline \multirow{2}{*}{$\begin{array}{l}\text { Marital } \\
\text { status }\end{array}$} & Married & 313 & $99(31.9)$ & $52(52.3)$ & $52(16.6)$ & \multirow{2}{*}{$\begin{array}{l}0.57 \\
0.449\end{array}$} \\
\hline & Non married & 131 & $41(31.3)$ & 18(43.9) & 18(13.7) & \\
\hline \multirow[t]{2}{*}{ Residents } & Urban & 97 & $23(23.7)$ & $9(39.1)$ & $9(9.3)$ & \multirow{2}{*}{$\begin{array}{l}3.93 \\
0.047\end{array}$} \\
\hline & Rural & 347 & 117(33.7) & $61(52.1)$ & $61(17.6)$ & \\
\hline \multirow[t]{2}{*}{ Occupation } & Agro- /Pastoralist & 249 & $86(34.5)$ & $46(53.5)$ & $46(18.5)$ & \multirow{2}{*}{$\begin{array}{l}3.13 \\
0.077\end{array}$} \\
\hline & Others & 195 & $54(27.7)$ & $24(44.4)$ & $24(12.5)$ & \\
\hline
\end{tabular}

Table 3: Socio- demographic characteristics and malaria among febrile study respondents (№ =444) 


\begin{tabular}{|c|c|c|c|c|}
\hline Factors & & № tested & № ${ }^{+v e}(\%)$ & $x^{2} ; p$ value \\
\hline \multirow[t]{2}{*}{ Sex } & Male & 180 & $13(7.2)$ & \multirow[t]{2}{*}{$6.40 ; 0.01$} \\
\hline & Female & 264 & $6(2.3)$ & \\
\hline \multirow[t]{4}{*}{ Age } & $2-14$ & 58 & $6(10.3)$ & \multirow[t]{4}{*}{$7.66 ; 0.05$} \\
\hline & $15-29$ & 241 & $12(4.0)$ & \\
\hline & $30-44$ & 111 & $0(0.0)$ & \\
\hline & $\geq 45$ & 34 & $1(2.9)$ & \\
\hline \multirow[t]{2}{*}{ Educational status } & Illiterate & 201 & $7(3.5)$ & \multirow[t]{2}{*}{$0.57 ; 0.45$} \\
\hline & Primary school and above & 243 & $12(4.9)$ & \\
\hline \multirow[t]{2}{*}{ Marital status } & Married & 313 & $9(2.9)$ & \multirow[t]{2}{*}{$5.10 ; 0.02$} \\
\hline & Non married & 131 & $10(7.6)$ & \\
\hline \multirow[t]{2}{*}{ Residents } & Urban & 97 & $5(5.2)$ & \multirow[t]{2}{*}{$0.23 ; 0.63$} \\
\hline & Rural & 347 & $14(4.0)$ & \\
\hline \multirow[t]{2}{*}{ Occupation } & Agro- / Pastoralist & 249 & $8(3.2)$ & \multirow[t]{2}{*}{$1.57 ; 0.21$} \\
\hline & Others & 195 & $11(5.6)$ & \\
\hline
\end{tabular}

Table 4: Univariate analyses of potential risk factors for brucellosis of the study patients (№ $=444)$ 


\begin{tabular}{|c|c|c|c|c|c|}
\hline Factors & & $\begin{array}{l}\text { № } \\
\text { tested }\end{array}$ & $\begin{array}{l}\text { № }{ }^{+v e} \text { at } \\
\text { overall (\%) }\end{array}$ & ${ }^{\star *} \operatorname{COR}(95 \% \mathrm{Cl})$ & $P$ value \\
\hline \multirow[t]{2}{*}{ Milk from large ruminant } & No & 332 & $49(14.7)$ & 1 & \\
\hline & Yes & 112 & 21(18.7) & $0.78(0.42 ; 1.42)$ & 0.419 \\
\hline \multirow[t]{2}{*}{ Milk from small ruminant } & No & 168 & 18(10.7) & 1 & \\
\hline & Yes & 276 & $52(18.8)$ & $1.12(0.57 ; 2.23)$ & 0.725 \\
\hline \multirow[t]{2}{*}{ Milk from camel } & No & 214 & $29(13.5)$ & 1 & \\
\hline & Yes & 230 & $41(17.8)$ & $0.64(0.35 ; 1.17)$ & 0.144 \\
\hline \multirow[t]{2}{*}{ Drinking raw milk } & No & 96 & $1(1.0)$ & 1 & \\
\hline & Yes & 348 & $69(19.8)$ & $27.71(3.59 ; 213.68)$ & 0.001 \\
\hline \multirow[t]{2}{*}{ Drinking of boiled milk } & No & 248 & $38(15.3)$ & 1 & \\
\hline & Yes & 198 & $32(1602)$ & $0.70(0.40 ; 1.24)$ & 0.222 \\
\hline \multirow{2}{*}{$\begin{array}{l}\text { Drinking milk from aborted } \\
\text { animal }\end{array}$} & No & 393 & $54(13.7)$ & 1 & \\
\hline & Yes & 51 & 16(31.3) & $2.87(1.49 ; 5.54)$ & 0.002 \\
\hline \multirow{2}{*}{$\begin{array}{l}\text { Touching of aborted } \\
\text { materials/fetus }\end{array}$} & No & 391 & $51(13.0)$ & 1 & \\
\hline & Yes & 53 & 19(35.8) & $2.82(1.16 ; 6.86)$ & 0.022 \\
\hline
\end{tabular}

${ }^{* *}$ COR-Crude odds ratio, Cl-Confident interval

Table 5: Multivariable analysis of risk factors for occurrence of brucellosis of the study patients 


\begin{tabular}{|c|c|c|c|}
\hline Factors & & Adjusted OR(95\% Cl) & $P$ value \\
\hline \multirow[t]{2}{*}{ Sex } & Female & 1 & \\
\hline & Male & $2.41(1.36 ; 4.26)$ & 0.002 \\
\hline \multirow[t]{2}{*}{ Educational status } & Illiterate & 1 & \\
\hline & Primary school and above & $0.76(0.40 ; 1.44)$ & 0.399 \\
\hline \multirow[t]{2}{*}{ Resident } & Urban & 1 & \\
\hline & Rural & $1.19(.53 ; 2.64)$ & 0.678 \\
\hline \multirow[t]{2}{*}{ Drinking of raw milk } & No & 1 & \\
\hline & Yes & $17.79(2.41 ; 131.32)$ & 0.005 \\
\hline \multirow[t]{2}{*}{ Drinking milk from aborted animal } & No & 1 & \\
\hline & Yes & $0.76(0.28 ; 2.02)$ & 0.577 \\
\hline \multirow[t]{2}{*}{ Touching of aborted materials/fetus } & No & 1 & \\
\hline & Yes & $2.50(1.01 ; 6.18)$ & 0.048 \\
\hline
\end{tabular}

\section{Supplementary Files}

This is a list of supplementary files associated with this preprint. Click to download.

- STROBEchecklist.docx 